\title{
Features of Greek Satyr Play as a Guide to Interpretation for Plato's "Republic"
}

Noel B. Reynolds

Brigham Young University - Provo, nbr@byu.edu

Follow this and additional works at: https://scholarsarchive.byu.edu/facpub

Part of the Political Science Commons

\section{Original Publication Citation}

“Features of Greek Satyr Play as a Guide to Interpretation for Plato's Republic," Polis: The Journal of the Society for Greek Political Thought, vol 29, No. 2, 2012, 234-258.

\section{BYU ScholarsArchive Citation}

Reynolds, Noel B., "Features of Greek Satyr Play as a Guide to Interpretation for Plato's "Republic"'" (2012). Faculty Publications. 1475.

https://scholarsarchive.byu.edu/facpub/1475 


\section{Features of Greek Satyr Play}

\section{as a Guide to Interpretation for}

\section{Plato's Republic}

Noel B. Reynolds ${ }^{1}$

Brigham Young University

August 21, 2012 


\begin{abstract}
:
The paper borrows from recent work by classicists on satyr play and demonstrates significant parallels between Plato's Republic and the structure, theme, and stereotypical contents that characterize this newly studied genre of ancient Greek drama. Like satyr play, the Republic includes repeated passages where metatheatricality can reverse the meaning. The frequent occurrence of all the stereotypical elements of satyr play in Plato's Republic also suggests to readers that they should be responding to Socrates's narration as they would to a satyr play, again reversing meaning by communicating a set of literary expectations to Plato's readers over the heads of Socrates's interlocutors. And as is frequently the case with satyr play, the political purpose of the drama is the critique of tyrannical government. The need for a systematically ironic interpretation of the dialogue is raised.
\end{abstract}




\section{Features of Greek Satyr Play as a Guide to Interpretation for Plato's Republic}

In recent decades, scholars from various fields have enriched the discussion of the Platonic dialogues by giving increased attention to their dramatic form. ${ }^{2}$ In general, such interpretations recognize that Plato's views, like those of a dramatist, will not usually be spelled out and defended explicitly in his scripts. Readers are expected to look behind the characters and their speeches; the views of the writer are recognized to be presented in the text only indirectly. They are to be ferreted out through inference, guided by sensitivity to literary elements. $^{3}$

An awareness of the distance between the speeches assigned to characters and the underlying thought of the author is, however, both an aid and an obstacle to understanding. On the one hand, if this interpretive assumption is correct, it becomes a necessary first step leading to a more complete understanding of the author's intent. But, at the same time, this assumption also introduces a host of new and less manageable questions, all of which are frequently and conveniently avoided in a more direct interpretive approach.

Yet the benefits far outweigh the difficulties. For Plato, the dramatic medium offered a powerful tool to increase the impact and enrich the implications of his writings. As Peter Euben points out, there is little in modern experience to prepare us for the profound and pervasive role of drama in Athenian collective life. ${ }^{4}$ In Plato's Athens the dramatic festivals were at the heart of the city's religious, political, and social culture. Through comedy, tragedy, satyr play, and 
dithyramb, the collective citizens of Athens were confronted in a dramatic context with their political and moral choices. In many plays, the analogies and references to contemporary events were specific. In other cases, the implications of general themes and attitudes were developed. In either circumstance, drama 'helped to shape the democratization of Athenian life' by clarifying and influencing the knowledge, values, and reasoning of the culture. ${ }^{5}$ Plato and others leveraged this drama-saturated culture in the development of written dialogues. ${ }^{6}$ Assuming that the dialogues were written to be read only—and not performed on a stage ${ }^{7}$ - the dimensions of drama introduced by actors and directors were not available to Plato. But the numerous elements of Athenian drama found in Plato's works testify to a significant and intentional link to this powerful tradition. Scholars have particularly noticed in Plato's Symposium a blending of the elements of tragedy and comedy with satyr play, ${ }^{8}$ and a representation of the City Dionysia itself, complete with contests. ${ }^{9}$

That Plato's writings have a dramatic character should come as no surprise, for, as Diogenes Laertius tells us, Plato wrote both poems and tragedies before taking up philosophy (Diog. L. 3, 6). ${ }^{10}$ Diogenes also cites other testimonies of Plato's intention to compete for a prize in tragedy (Diog. L. 3, 8) and describes his close working relationship with the comic poet Epicharmus (Diog. L. 3, 12). The ancient sources 'are unanimous in mentioning that Plato wrote tragedy'. ${ }^{11}$ Further emphasizing Plato's involvement in mimetic things, Diogenes credits him with having brought the books of the mime writer Sophron to Athens and being a choregus in the Athenian theater (Diog. L. 3, 13 and 4). 
In both dramatic production and the dialogues of Plato, the writer invites the audience to see the complex world of the actors from an external perspective that none of the particular characters can fully share. No single character, nor even all the characters together, can be assumed to know everything the author knows and intends the audience to know that he knows. Consequently, an adequate interpretation will depend on indirect and necessarily ironic forms of communication between the writer and the reader, on forms of communication that are not mediated understandingly by the characters. No character-possibly not even Socrates — can be assumed to be speaking for Plato. ${ }^{12}$ The good writer must provide clues to the audience that are invisible to the characters of the drama, thus allowing the writer and the audience to share the same comprehensive point of view while leaving the characters in their own more limited and defined worlds.

In interpreting Plato, one major difficulty arises from the fact that Plato and other dialogue writers were inventing their own dramatic genre. When writers employed tragic or comic forms, readers would have had a ready set of conventional expectations to help them place the characters' speeches in the necessary context for properly understanding the author. A familiarity with genre is one of the most powerful resources for an author in this process of indirect communication. When readers know they are reading tragedy, certain attitudes and expectations are assumed that enable them to anticipate awful fates and eventualities as occasions for reflecting on the deep and problematic aspects of human life, thus giving the script richer meaning at every turn. Similarly, the 
reader of comedy is prepared not to take outrageous statements or claims too seriously, and not to underrate the possibly serious implications of jokes. Plato's dialogues have been noticed to contain both tragic and comic elements, but no one has argued that they are simply tragedies or comedies. And what are we to make of a dramatic writing that contains both kinds of elements in the same text?

Combining tragedy and comedy actually has some possibilities that would appeal to a philosophical writer. Because tragicomedy has emerged strongly, particularly since Shakespeare, as a distinctive dramatic form, we have some understanding of its dynamics. The attractiveness of tragicomedy for philosophy lies in its confusion of human responses. When we are provoked to laugh at serious (even tragic) matters relating to the human condition, we are simultaneously provoked to wonder whether that laughter can be appropriate. This ambivalence is essentially the same as that which underlies the questioning stance basic to philosophy as Plato portrays it. We cannot decide whether or not we should laugh without committing ourselves on the big questions of life, the perennial philosophical questions. And so tragicomedy might even be designed to lead us in specific directions in our philosophizing, or at least to reward us when we go in the philosophical directions the author believes most correct.

In Symposium, Plato has Socrates promote the view that comedy and tragedy might profitably be combined. Our reporter wakes early in the morning to see Socrates arguing with the fast-failing Agathon and Aristophanes, and maintaining against them that the same man could write comedy and tragedythat the tragic poet could be a comedian as well. Plato's Socrates is reported 
variously in the dialogues defending opposite positions on this question.

This contradiction deserves brief discussion here. At the end of the Symposium, Aristodemus awakens to see Socrates, Agathon, and Aristophanes still arguing: 'As to most of the talk, Aristodemus had no recollection, for he had missed the beginning and was also rather drowsy; but the substance of it was, he said, that Socrates was driving them to the admission that the same man could have the knowledge required for writing comedy and tragedy — that the fully skilled tragedian could be a comedian as well' (223D). ${ }^{13}$

In the Republic's discussion of imitation as it relates to different forms of poetry, Socrates and Adimantus conclude 'that there is one kind of poetry and tale-telling which works wholly through imitation ... tragedy and comedy'. $(394 \mathrm{C})^{14}$ Adimantus then perceives that Socrates is really raising the question 'whether we shall admit tragedy and comedy into our city or not' (394D). Socrates only gives a qualified endorsement of this conclusion, indeed, he himself concludes something else: The logic of their discussion on specialization and imitation leads them to the admission that ('unless I mistake') 'the same men cannot practice well at once even the two forms of imitation that appear most nearly akin, as the writing of tragedy and comedy' (395A).

Shorey, in a footnote, notices the contradiction with the concluding lines of the Symposium and explains it away by pointing out that, for Plato, poetry is not a science or an art but rather inspiration. ${ }^{15}$ But Shorey does not recognize the strong possibility that, in passages such as these, Plato may be making subtle reference to his own writings. He may be the unmentioned writer sufficiently 
talented to produce both tragedy and comedy. ${ }^{16}$

If the specialization rule in the Republic is viewed as having merely a limited dramatic role, rather than being a cosmic truth, the contradiction might naturally be intended as an indicator of ironic statement. Contradictions of various kinds have been recognized by students of irony as among the most effective tools for warning readers of ironic elements in a text. ${ }^{17}$

In the Republic, Thrasymachus, Glaucon, Adimantus, and company are not stock comic or tragic characters. Nor does the action of the dialogue fit either of these genres well. Plato wants to present the action of the dialogues in the guise of philosophical discussions among intelligent people who are in full control of their faculties. Where intelligent characters are aware only of a serious philosophical discussion, how can the reader be warned to look at the conversation from a greater distance and to enter into a conversation with the author, rather than seeing the conversation between the interlocutors as the primary objective? The first and most satisfactory answer to this is that there are many devices of irony available that can be employed to signal such distance to an audience without alerting the characters. ${ }^{18}$ But for his contemporary readers, it would also have been possible for Plato to decorate his dialogues with some of the elements of conventional dramatic forms, alerting his readers to the kinds of expectations they should bring into play as they read.

The notion of combining genre elements turns out to be a helpful clue. It is not well known outside the world of classical scholars that satyr plays provided ancient Greeks with an entertaining mixture of tragedy and comedy. ${ }^{19}$ While only 
minuscule amounts of a once-large corpus of these satyr plays have survived to our day, scholarly developments in the last three decades have greatly extended our understanding of this phenomenon in Greek drama. Drawing on these studies, this paper will argue that Plato incorporated significant elements of stock satyr play material in his dialogues and particularly in the Republic. This study does not claim that the Republic is a satyr play, nor does it discount interpretive work done in light of tragic and comic elements in the Republic. The conclusions presented in this paper do not exceed the assertion that Plato deliberately wove recognizable elements of satyr play into this dialogue as a means of invoking conventional expectations associated with this established literary genre. In so doing, he gave himself an additional, powerful control on meaning in his own new dialogue form.

This argument will delineate the many and pervasive ways in which Plato conjures up the image of the Greek satyr play throughout the Republic to establish a mocking and humorous tone as a guide for the reader of the dialogue. It was important that Plato use such devices to signal the ironic character of the text to the readers, because Socrates's ironic stance must be credibly hidden from the other interlocutors, whose roles require that they take the conversation seriously in every respect. The ironies seen by Glaucon and Adimantus are of no consequence compared with those perpetrated by Socrates (and more particularly Plato) upon them. The device of liberally decorating the dialogue with stock elements of satyr play provides readers with signals that are invisible to the interlocutors, and thus perfectly serves Plato's purpose. Among the interlocutors, 
only Socrates, as the narrator of the Republic, was allowed enough perspective to see the whole in the same way as Plato's readers.

Because of the relative obscurity of the Greek satyr play even among scholars, I will preface my discussion with some relevant background information. The insights into satyr plays that will be presented here are derived from the relatively recent work of a handful of classicists. ${ }^{20}$ While some contend skeptically that sources for the study of satyr play are too few to allow for sweeping generalizations, by taking advantage of recent papyrus discoveries and by profiting from the work of their predecessors, these classicists have greatly expanded our knowledge of this classical genre of dramatic literature. It is probably fair to say that the state of the literature in this area before 1970 was such that the kinds of connections between Plato's Republic and the Greek satyr play demonstrated in this paper would have been difficult to draw. The information on satyr play used in this analysis is drawn substantially from Dana F. Sutton's 1980 treatise, ${ }^{21}$ in which he argued powerfully against the traditional reluctance of classicists, that even this highly fragmentary literature could be analyzed productively for a certain range of useful conclusions. In his own more cautious approach, Richard Seaford also provides supporting comments for this new enterprise in the introduction to his commentary on Euripides's Cyclops. ${ }^{22}$

In what follows, I depend principally on these sources, since the studies of these two scholars and their associates supersede and draw earlier scholarship together in a comprehensive way. The intent in this paper is not to add to our understanding of satyr plays, but only to apply what has recently been learned 
about them to Plato's Republic. ${ }^{23}$

The satyr play appeared early in Athens, and was traditionally linked to the tragedies in the annual competition at the festival of Dionysus. The classical tetralogy submitted by each competitor included three tragedies and one satyr play. ${ }^{24}$ This suggests that, to the extent Plato did compete in such festivals, he would have written satyr plays himself. Aelianus reports that Plato had actually delivered such a tetralogy to the actors before the famous incident in which he heard Socrates, whose effect on him, like that of the mythological siren, caused him to desert the contest before the performance, and abandon the writing of tragedy (Ael. Varia Historia 2, 30). ${ }^{25}$ Though the satyr play dealt with tragic themes, it did so with the language of ordinary life and in the context of exotic settings and fabulous characters. ${ }^{26}$ Without sacrificing serious themes, this genre avoided heavy emotional involvement and allowed viewers to laugh. The satyr play provided comic relief, often without abandoning tragic themes and without depending extensively on the obscene. The characteristically happy endings of the satyr plays also distinguished them from the tragedies they accompanied in the competitions. ${ }^{27}$ In addition, the inclusion of satyr play can be viewed as a concession to public demand for more Dionysian elements in the competition. ${ }^{28}$ Professor Sutton's chapter on generic stereotypes sparked my first suspicion that Plato might be using satyr-play themes in the Republic. Although the reader may note that certain characteristics cited by Sutton as typical of satyr play are also commonly found in other genres, the observed correlation between the satyr play and works of Plato, outlined in this paper, is not diminished. The 
strength of my thesis does not depend on any individual element, but rather upon the realization that, in the Republic, the combination of narrative elements scholars find to be characteristic of satyr plays is present in its entirety. In addition, there are strong parallels between Socrates and prominent characters in satyr play, namely, Herakles and Silenus. This paper briefly summarizes these correlations of largely uninterpreted narrative elements. The complete and pervasive correlation suggests that Plato may have borrowed these elements of satyr play intentionally and systematically as a device for signaling to his audience how the Republic should be read.

\section{The Character of Socrates}

The most obvious characteristic of satyr play is of course the presence of a satyr or satyr chorus. 'There is no evidence for a satyr-less satyr play'. ${ }^{29}$ The unique attributes of satyrs and the typical roles they play are integral aspects of the satyr-play genre.

The satyr is a popular figure in the Greek tradition. This is undoubtedly due in part to his close association with gods and heroes such as Dionysus and Herakles, but the satyr's colorful personality certainly contributes additionally to his appeal. Satyrs are noted for their gluttony, lust, and heavy drinking. Their questionable character is further illustrated by their frequent employ of trickery, magic, and deception. Yet despite their boisterous ways and common speech, satyrs are depicted as possessors of uncommon wisdom and understanding.

In Greek literature, the satyr's personality is a meaningful paradox. Physically satyrs are part goat (or horse) and part man, and are characterized by 
uncommon ugliness. This depiction fits well their personality, for, on the one hand, the satyr 'is a beast, a bundle of raw appetites, no more than a caricature of a human being'.

But by an interesting paradox the satyr is in some kind of communion with superhuman forces. He has an uncanny ability to see past the facade of reality and apprehend Nature's inner workings. He knows all manner of arcane lore; he can raise the dead and produce other supernatural effects. Thus, like man, the satyr has a higher and lower self. But, unlike all but the healthiest of men, the satyr lives in harmony with nature and his higher and lower selves are not in conflict. The satyr ... has been pressed into service as a symbol of man in his ideal state living according to Nature, uncorrupted by civilization and its discontents, not neurotic. $^{30}$

Such a characterization brought him popularity among the Greek people as well as versatility among the playwrights.

No chorus of satyrs is represented by any of the actors in the Republic. But Socrates's description of the class of guardians comes close to giving them some qualities of the satyr chorus. In particular, the reader of Sophocles's Ichneutae will be reminded of the similar way in which Glaucon's guardians, like the satyrs, are to be treated like animals. Even more precisely, scholars have noticed the presentation of the satyr chorus in Ichneutae as a pack of hunting dogs, ${ }^{31}$ recalling the Republic's specific characterization of the guardians (375E). 


\section{Socrates as satyr.}

Even clearer is the analogy between Silenus and Socrates. Although not half goat, Socrates, the principal protagonist in the Republic, typifies many of the prominent characteristics of satyrs. ${ }^{32}$ Such a comparison will not surprise the reader who remembers Plato's Symposium, in which, during the round of speeches in praise of Eros, drunken Alcibiades offers a speech in praise of Socrates. Under the influence of wine as a truth serum (214E, 215B, 217B), Alcibiades launches into an encomium on Socrates describing him in detail as a satyr like figure with characteristics matching both of the satyric prototypes. ${ }^{33}$ Somehow the mixed reputation of satyrs comes out mostly positive when applied to this enigmatic man.

Socrates, he says, is like the Silenus figures one can buy at the market. When opened up, there are little gods inside. Socrates also reminds him of Marsyas, the other famous satyr. In the first place, no one can deny that Socrates

has the physical appearance of a satyr. ${ }^{34} \mathrm{He}$ is also just as impudent. He is a better piper than Marsyas, and his words, like the magical tunes of Marsyas, can show which mortals are fit subjects for divine initiation. When he speaks, Alcibiades, like others, is 'smitten with a kind of sacred rage, worse than any Corybant' (215D). Socrates, the 'latter-day Marsyas' has often left Alcibiades 'in such a state of mind' that he could not go on living in the same manner (216A). Socrates is the only man alive that can make him ashamed of his conduct.

As Alcibiades continues his praise of Socrates, he mentions other ways in which Socrates is like a satyr. No one really knows him. He often hangs around, 
gaping at beautiful people and pretending to be uninformed and ignorant, just like Silenus. But all of this is just his outer casing. If you open him up, he is full of temperance and sobriety. He doesn't care about good looks, money, or honor. His whole life is spent in his ironic game, laughing privately at the entire world. But once opened up, the little figures inside him are golden, godlike, and beautiful (216D-E).

Like a satyr, Socrates is absolutely unique; there is no one else like him (221C). He can drink enormous amounts and never become drunk (214A). He walks barefoot in the snow without concern (220B). His arguments are just like Sileni that open up. When you first hear them they are laughable, all wrapped up in the ordinary language of common life (like the language of a satyr play). But if you open them up they are godlike and help seekers on their way to true nobility (222A). Both he and his ideas are better compared to Sileni than to human beings. In other works, Plato suggests the satyr comparison in numerous ways. The trial imagery of the Republic reminds us constantly of Socrates's unsuccessful defense before the Athenian jury. Marsyas's demise also occurred at a trial or contest occasioned by Apollo's jealousy when people praised the satyr flutist's music over Apollo's harp. The Muses could not choose a winner until Apollo challenged Marsyas to play his instrument upside down while singing, a task possible for a harpist but not for a flutist. ${ }^{35}$ The penalty Apollo chose to exact of Marsyas, like his latter-day worshippers, the Athenian prosecutors of Socrates, was an unreasonable death — being flayed alive. In light of this ready analogy, one cannot miss the tragic irony with which Socrates tells Glaucon that they are not 
doing anything new in preferring Apollo and his harp to Marsyas and his flute (399E).

There are also implicit parallels suggested in the Republic between Socrates and Silenus, the other famous satyr to whom Alcibiades compared him. A significant number of known satyr plays trace the upbringing of gods and heroes. ${ }^{36}$ Not infrequently Silenus is the principal pedagogue. Obviously, Socrates plays the role of pedagogue in the education both of the interlocutors in the conversation and in their imaginings of the guardians and philosophers that will lead Glaucon's city. In addition, Silenus and the satyrs are known for rapid and often comical swings from courage to cowardice. In the Republic, Socrates, as narrator, describes himself as having this same characteristic. In spite of his evident domination of the discussion of justice, Socrates repeatedly claims to have cowered in fear, first before Thrasymachus (336D) and then before each new wave of ridicule (450D, 472A, 506D). In each case, he is forced to continue by his companions and states his arguments without a hint of difficulty.

Plato also indirectly invokes the popular belief that if you can capture a satyr, you can compel him to reveal mythological secrets or entertain you with mythological songs. In a similar manner, Socrates was arrested and compelled by Polemarchus to remain in the Piraeus and entertain him and his friends with imaginative philosophical talk.

The portrayal of Socrates as the satyr of the play, and the comparison with Silenus, does have the difficulty that Silenus is often represented in these plays as an unscrupulous entrepreneur. Furthermore, the satyrs are known for bumbling 
and lusty behavior. But there are two strong reasons to override this objection. The first is simply the previously noted paradoxical personality of the satyr, which fits Plato's purposes in the characterization of Socrates. The second and most obvious is the description of satyrs offered by Plato himself. In the Symposium, Alcibiades bids his audience not to pay attention to either Socrates's pretended ignorance or his feigned interest in sexually attractive people. When you know him, inside he is something else altogether (216D-E).

Plato's description of satyrs, as given by Alcibiades, enables us to understand how Socrates can serve both as the satyr and as the hero. In fact, a person well-versed in the events of the life of Socrates may be led to conclude, as did Alcibiades, that one will 'never find anyone like Socrates, or any ideas like his ideas, in our times or in the past - unless of course, you take a leaf out of my book and compare him, not with human beings, but with Sileni and satyrs' (221D).

\section{Socrates as Heraklean hero.}

Closely associated with satyrs and Sileni, and typically playing the role of hero in Greek satyr play, is Herakles. His extreme popularity in fifth-century Athens is attested by his frequent and favorable appearances in Greek literature of the time. ${ }^{37}$ The Herakles figure lent itself particularly well to comedy and satyr play. 'The satyrs of course were the followers of Dionysus, and Herakles's association with Dionysus may have contributed to the importance of his role in the genre' ${ }^{38}$ The association between satyrs and Herakles is further attested by numerous vase paintings. F. Brommer lists fifty-nine vases with paintings of Herakles and satyrs, or of satyrs dressed as Herakles. ${ }^{39}$ The popularity of Herakles 
and his close association with satyrs suggest ample motivation for Plato to have used references to these characters in constructing the ethos of the philosophic hero, Socrates.

The Heraklean image is suggested in several dialogues. In the Apology Socrates's struggle to determine the meaning of the oracle is subtly compared to Herakles's labors (22A). The dialogues as a whole give us an almost Heraklean picture of Socrates wandering through life facing one challenge (labor) after another, and always coming off the victor. ${ }^{40}$ In the Phaedo, Socrates states that arguing with two opponents is something not even Herakles would do (89C). A similar analogy is made in Euthydemus where Socrates's debate with two sophists is compared to Herakles fighting the hydra (297C-E). In the Cratylus, Socrates compares himself to Herakles indirectly, but obviously, claiming to have put on the lion's skin (411A).

Others have noticed that in the Republic, particularly, Plato leads us to identify in Socrates the Heraklean image. ${ }^{41}$ For example, roles played by Herakles such as the 'enemy of evil doers', liberating captives from barbarians and despots, fit well with Socrates's role in the Republic.

More significant still are the underlying analogies between the Herakles myth and Plato's intended characterization of Socrates. In Plato, as among nearly all philosophers, Herakles was received with general admiration. ${ }^{42}$ Some viewed him as the ethereal wise man. Others viewed him as the embodiment of justice and areté $^{43}$ Among the people Herakles also had widespread appeal. Most of his popularity was due to the fact that according to legend Herakles was born a man, 
progressed to a hero, and eventually became a god. ${ }^{44}$ His journey makes him a

model 'of the aspirations of mankind' ${ }^{45}$ just as Plato represents Socrates to be. The irony Plato would not want us to miss was that while the Athenians put Socrates to death, Herakles was most popular in Athens, and they claimed to be the first to make him a god. ${ }^{46}$

\section{Generic Stereotypes of Satyr Play}

Among the principle features of satyr play, Sutton notes the use of 'a relatively few stereotypes of situation, theme and characterization ${ }^{47}$ In their writings both Sutton and Seaford identify and describe a number of stereotypes which taken together are distinctive of the satyr play genre. I will indicate below the ways in which these frequently recurring themes, scenes, and personages, which can be seen as the distinctive conventions of satyr play, are also readily identifiable in Plato's Republic. Again, it is important to understand that these themes and elements of satyr play are not all unique to satyr play, as many of them occur in other genres. Rather, it is their occurrence together in the same work that is characteristic of satyr play. While I find all fifteen of Sutton's stereotypes instantiated in the Republic, I will only discuss eleven that are most obvious and that I have not already mentioned above more briefly.

\section{The Ogre.}

In many satyr plays, a notorious villain—often an ogre, an eater, killer, or enslaver of humans (or satyrs) — is 'killed or at least subdued'. ${ }^{48}$ Although in the Republic there is no specific villain clearly corresponding to this description, 
Socrates describes tyrants in general through a legend which holds that 'he who tastes of the one bit of human entrails minced up with those of other victims is inevitably transformed into a wolf' (565D-566A). Furthermore, Thrasymachus stands forth boldly as spokesman for and defender of these tyrants. An additional connection arises from the language of Socrates in this same passage that links tyrants with wolves. In Book I, when Thrasymachus first enters the dialogue, he is specifically identified as both a wolf and a wild beast who 'hurls himself upon [them] as if he would tear [them] to pieces' (336B, see below). Recovering magnificently from his initial fright, Socrates, like the satyr play hero Herakles, defeats and tames Thrasymachus through superior mental powers - in this case, powers of argumentation (354B). In Glaucon's words, Thrasymachus gave up the argument 'as if he were a serpent [Socrates] had charmed' (358B).

Sutton has shown that scholars who have read Polyphemus's long speech in Cyclops as a parody of sophism are mistaken (especially as many of its elements are already present in its prototype in the Odyssey). ${ }^{49}$ But it seems safer to invert the argument. Thrasymachus's argument in Book I of the Republic parodies the thinking of satyric ogres such as Euripides's Polyphemus, and of satyric rascals such as Critias's Sisyphus. ${ }^{50}$ Thrasymachus's viewpoint is monstrous and criminal, and it reminds Plato's readers of the viewpoint of the half-humorous monsters and criminals who abounded on the satyric stage. While endorsing the view that Thrasymachus, like Polyphemus, is more of tyrant than a sophist, Patrick O'Sullivan proposes a different analysis to reach that conclusion..$^{51}$ 


\section{Hospitality abused.}

The satyrs in these plays are often unfortunate guests, in bondage or

otherwise abused. ${ }^{52}$ In Cyclops, for example, the satyrs are held captive in a cave by the ogre Polyphemus. This image recurs in the Republic with Socrates's analogy of the captives in the cave who were shown deceptive images by their captors $(514 \mathrm{~A}-515 \mathrm{~A})$. Such mistreatment places the host at odds with all the norms of civilization and with the gods themselves. According to Greek tradition, guests must be shown a highly developed form of hospitality. This may also help explain Plato's emphasis on the strange circumstances which establish the conversation of the Republic. Against his wishes, Socrates is arrested by Polemarchus and company and is compelled by this superior force to come as a 'guest' to Polemarchus's house. Polemarchus promises a dinner and a spectacle in return for conversation (327B-328B). Socrates gives them conversation, but is neither fed nor entertained.

\section{Escapes and rescues.}

In connection with the theme of a guest in bondage, the satyr play often recounts the guest's escape or rescue. ${ }^{53}$ Socrates (philosophy) and justice are put on trial in the Republic (318B, 419A), and will not be acquitted unless Socrates meets some extremely difficult or even impossible requirements in making his defense $(360 \mathrm{E}-361 \mathrm{D}, 450 \mathrm{~A}, 451 \mathrm{~B}, 474 \mathrm{~A}, 612 \mathrm{C}-\mathrm{D})$. In the course of the argument, Socrates consistently uses the language of escape and rescue (326D, 368B, 457E, 474A, 474C, 589D). He notes to Glaucon, for example, that they are in danger of being drowned by the waves of ridicule and that they need a dolphin or other 
miraculous rescuer (453D). In the course of the discussion, he describes the unjust man as he who 'enslaves the best part of himself to the worst' (589D). A primary intent of the entire dialogue is to save the soul from this more dangerous, but less appreciated form of captivity and abuse.

In addition, Socrates explains that youths with a philosophical nature are bound to be corrupted, for all people are sophists and will persuade them to use their wonderful talents in perverted ways. This disappointing fate is assured unless the youths benefit from some divine rescue (492A) or divine intervention (493A).

\section{Contests.}

In satyr play, the defeat of the villain is often accomplished through athletic competition or other form of contest. ${ }^{54}$ Dialogue is the natural arena in which Socrates can take on Thrasymachus, the notorious sophist, and his other captors. Making the connection to satyr play contests even more explicit, Socrates compares the ensuing debate to both a wrestling match (544B) and a foot-race $(613 \mathrm{C})$. Socrates succeeds in restoring the reputation of justice by defending her under virtually impossible restrictions of argument (612D).

Sutton also notes that the discussion of athletic training and equipment surrounding these contests is so prominent in the satyr plays that it almost constitutes an independent theme. ${ }^{55}$ The Republic devotes many pages to the athletic training of the guardians - 'Athletes in the greatest contest' (403E)considering many matters in amusing detail. Much of the discussion relating to their equipment is to be found in the attention given to the beliefs with which they 
must be equipped in order to be effective guardians.

\section{Trickery.}

Thrasymachus's complaints against Socrates's trickery (340D, 341C, 487E) are certainly not unfounded. As illustrated by Odysseus, the forerunner of all satyr play heroes,${ }^{56}$ some element of trickery is commonly instrumental in winning the contest or engineering the escape. ${ }^{57}$ Sutton explains that Athenian audiences did not hold these heroes morally responsible for this kind of deception. ${ }^{58}$

An ironic interpretation of the Republic necessarily shows Socrates leading Glaucon, Adimantus, and others along in a revelation of the implications of their desires and beliefs, but not his own. ${ }^{59}$ It must be remembered in this connection that Socrates repeatedly and mysteriously warns the others not to let him deceive them (450E-451A, 507A). He also uses arguments and approaches that would be difficult to defend. Two prominent examples are his arithmetic formulas for the eventual breakdown of the Ideal City (546) and for the comparative happiness of just people (587C). The tradition of the satyric hero using morally excusable trickery enables us to see Socrates doing the same without violating his commitment to the highest standards of morality. It also helps us understand why Plato allows Socrates to refute Thrasymachus with weak arguments.

Sutton also notes that 'characters treated with more respect in serious genres might also have been presented as tricksters . . in satyr plays' ${ }^{60}$ Furthermore, intellectuality in a popular reputation 'could have been viewed as rascality for humorous purposes' ${ }^{61}$ This characteristic often applies to both the 
hero (Herakles or Odysseus) and to Silenus, the father and leader of the satyrs.

\section{Magic and miracles.}

Sutton lists several specific magical objects and operations that are noticeably recurrent in known satyr plays. ${ }^{62}$ Many of these same objects are present in the Republic as key elements of stories recounted by Socrates to make his points. The magic ring of Gyges with its ability to make its wearer invisible is one such object which plays a prominent role in the dialogue (359D). The ring is mentioned again later in conjunction with another satyr-play favorite, the cap of Hades, which also confers magical invisibility upon its wearer (612B). The reference to miraculous rescue by dolphins (453D) was mentioned previously, and the Republic concludes with the miraculous story of the resurrection of $\operatorname{Er}(614 \mathrm{~B})$.

In addition, the discussion of false opinion in the Republic invokes the imagery of magic and sorcery. In Book III Plato writes: 'And the victims of sorcery I am sure you too would say are they who alter their opinions under the spell of pleasure or terrified by some fear. Yes, he said, everything that deceives appears to cast a spell upon the mind' (413C). Later, as Socrates entertains the possibility of reintroducing poets into his Callipolis, he calls attention to the magic of poetry. 'Do not you yourself feel her magic and especially when Homer is her interpreter' (607C). As argued by Elizabeth Belfiore, ${ }^{63}$ Plato also uses imagery of magic and trickery in association with the teaching and methods of Socrates. In so doing, he is attempting to depict Socratic philosophy as a countermagic, in opposition to that employed by the poets and sophists.

Another common miracle in satyr plays is the anodos-epiphany in which 
people rise out of the ground, either as newborns or as people returning to this life from the Underworld. ${ }^{64}$ Socrates's Phoenician Tale, which was designed to teach people that their assigned class is natural and that they are children of the land, develops this anodos phenomenon into a general explanation and justification for the conditions of life (414C-415D). More important still is the Myth of Er, employed by Socrates in the final pages of the Republic as a mythological reaffirmation of the principles of justice he has expounded. In the myth, Er rises from his funeral pyre and relates the hero's return to mortality from the underworld. $^{65}$

Yet a third invocation of the anodos theme is especially creative and links the dramatic and philosophical themes of the dialogue. In the celebrated cave analogy of Book Seven, the dwellers of this underground cavern are held in place from birth by fetters — presumably false cultural beliefs — and can only be released and hauled to the surface by someone who has knowledge of the true world outside the cave $(514 \mathrm{~A}-518 \mathrm{C})$.

\section{Exotic setting.}

Sutton explains that the settings of satyr plays tend to be exotic in some way. ${ }^{66}$ Foreign locations, sea shores, caves, ${ }^{67}$ and the countryside are common choices. Although the Piraeus would not ordinarily be described as exotic, it is nonetheless distinctive when compared to the Athenian agora and private homes where most of Plato's dialogues are set. Being a seaport, it is full of foreigners and sailors - people with alien ideas — and is a fit place for the inauguration of a festival to a Thracian goddess and an outlandish discussion of the best regime. 
More importantly, the Republic features the metaphor of captives in a cave, which is equated to the city. A cave is similarly the location of the captive satyrs in Euripides's Cyclops. This prominent metaphor is indicated explicitly in the opening word of the Republic as Socrates says, 'I went down' (katebên, 327A) to the Piraeus, using the same verb that is used later when the enlightened philosopher goes back down into the cave (katabas, 516E). ${ }^{68}$ The Piraeus (like Athens) becomes a cave, and remains so for the entire dialogue.

Plato's focus on the cave analogy in the Republic may have served almost like a waving flag to a contemporary Athenian audience, calling attention to the satyric elements in the dialogue. A cave was just where one might look for satyrs. Greek dramatists referred often to caves as a background for the action of their plays, and caves were probably part of the stage setting of many Greek tragedies and comedies, ${ }^{69}$ but, according to Vitruvius, they were stock components of the stage scenery for satyr plays (De architectura, V. c. vi. 9). Plato's cave analogy links the city and the theater even more clearly by portraying the citizens as a captive audience watching shadow play of a puppet show on the wall in front of them. The men who manipulate these shadows, and thus the beliefs and understanding of the citizenry, are obvious targets of the same complaints that Socrates brought against poets earlier in the dialogue.

\section{Folkloric elements.}

Satyr plays often feature narrative elements borrowed from folklore, including the ogres, tricksters, and miracles already mentioned. ${ }^{70}$ Many of the more common examples cited by Sutton also occur in the Republic. 
(a) Invisibility-producing rings and clothing:

The ring of Gyges described by Glaucon can make its wearer invisible whenever the collet is turned inward, thus freeing the wearer from detection in the commission of any wicked deed (359D). The cap of Hades is mentioned later as having the same power (612B).

(b) Blinding and healing of the blind by looking at the sun:

Though it is unique in its presentation, the cave allegory and the process of overcoming the darkness-induced blindness of cave dwellers by getting them to look at the sun inevitably invoke this folkloric notion. In the Callipolis, the philosopher must rule, for only he is not blind (484D). His keen vision is a product of being forced to look upon the sun (540A).

(c) Resurrections or resuscitations:

Again, the resuscitation of Er is a striking example (621B).

(d) People made from clay:

The folklore account of human creation from clay may appear in the satyr play Pandora, and is echoed in Plato's anodos incident. The people in Glaucon's city are to be told that they were made from the earth, with admixtures of gold, silver, or bronze (415 A-B).

(e) Other:

The Republic includes obvious references to a number of similar narrative elements taken from folklore that are not included in the list that Sutton draws from extant satyr plays. Examples of these include folklore beliefs related to wolves and dolphins. 
(1) The first is indirectly invoked when Thrasymachus makes his threatening entry. Socrates comments: 'And I, when I heard him, was dismayed, and looking upon him was filled with fear, and I believe that if I had not looked at him before he did at me I should have lost my voice' (336D). The sense of this statement depends on the folklore belief that if a wolf sees a person before he or she sees it, the person will be struck dumb.

(2) A second example occurs much later in the description of the tyrants. As an exploiter (eater) of his people, the tyrant, like the eater of human sacrifices in Arcadia, becomes a wolf (565D-E).

(3) The folklore belief in miraculous rescues of shipwrecked sailors by dolphins appears, as mentioned above, when Socrates foresees the wave of ridicule coming in upon their argument and suggests that they may need such a rescue (453D).

\section{Personified abstraction.}

As is common in folklore, numerous personified abstractions also show up in satyr plays. ${ }^{71}$ Because specific satyr plays bear their names, Moirae (fate) and Momus (blame) are prominent among these. Momus is even used as a satyr play title by both Achaeus and Sophocles. Both Moirae and Momus occur in the Republic as personified abstractions (617C, 487A) as do also justice and philosophy (368C, 612C-D, 536B-C). Justice itself is the subject of two known satyr plays-Aeschylus's 'Dike' Play and Sophocles's Inachus. ${ }^{72}$

Additional examples in the Republic are numerous. In one passage alone, Socrates introduces four-impudence (hybris), anarchy, prodigality, and 
shamelessness. Describing the evolution of democratic man, Socrates says: And when they have emptied and purged all of these the soul of the youth that they have thus possessed and occupied, and whom they are initiating with these magnificent and costly rites, they proceed to lead home from exile insolence and anarchy and prodigality and shamelessness, resplendent in a great attendant choir and crowned with garlands, and in celebration of their praises and euphemistically denominate insolence 'good breeding', licence 'liberty', prodigality 'magnificence', and shamelessness 'manly spirit'. [560E]

Hybris, which leads the returning parade, is the name of another satyr play by Sophocles. Of course, Hybris is the mother of Pan, and Hybris also appears to be the name of a satyr depicted on a Munich pelike. ${ }^{73}$

\section{Ridiculous scenes.}

Satyr plays always seem to include scenes in which ridiculous or socially incongruous behavior takes place on stage. ${ }^{74}$ In the Republic Plato certainly incorporates these kinds of visual jokes. In discussing the role of women in the newly founded city, Socrates asks: 'What then, said I, is the funniest thing you note in them? Is it not obviously the women exercising unclad in the palaestra together with the men, not only the young, but even the older, like old men in gymnasiums, when, though wrinkled and unpleasant to look at, they still persist in exercising? (452A-B)'.

A similar attitude is shown in Socrates's conjuring up of a scene in which 
everyone in the city over the age of ten docilely marches off to oblivion leaving all the children in the care of himself and Glaucon (541A). The treatment of the guardians and their offspring as dogs, or animals to be herded and kept in pens, maintains the same joking posture (416B, 440D, 459A, 460D, 466D, 537A, 539B). ${ }^{75}$ Many other scenes could also be mentioned for their tendency to maintain the farcical tone of the dialogue. I recognize that distinguished scholars have read these passages as serious proposals, but I would offer that the fact that they are so incongruous from any common sense perspective, invites us to entertain the possibility that they are not meant to be taken seriously, a possibility that would be quickly confirmed by the recognition of the satyr play mode installed by the author.

Less obviously farcical in tone, but more explicitly ridiculous in fact, is the introduction of the philosopher-kings as the government of Glaucon's purged city. Socrates advances this 'greatest wave of paradox' recognizing that 'it is likely to wash us away on billows of laughter and scorn' (473C). Glaucon immediately confirms that the author of such a proposal will be seen by leading enlightened citizens as deserving to be both 'scorned and flouted' (474A).

\section{Satyr drama and the invention of culture.}

The analysis François Lissarrague brings to satyr drama echoes many of these findings of Sutton, but adds another that we could also see as a feature of Republic:

Frequently the subject of the satyr play is tied to a discovery or an invention: of wine, for example, or music, metallurgy, fire, or the first 
woman, Pandora. That is, everything takes place as if satyrs were a means to explore human culture through a fun-house mirror; the satyrs are antitypes of the Athenian male citizenry and present us with an inverted anthropology (or andrology) of the ancient city-state. . . .

Satyric drama, by contrast [with tragedy], plays with culture by first distancing it and then reconstructing it through its antitypes, the satyrs. It does not seek to settle a controversy, nor to bring man face to face with his fate or the gods. It plays in a different key, with the displacement, distortion, and reversal of what constitutes the world and culture of men.... Satyrs use the medium of parody to reveal a world under the aegis of Dionysos. They appear as blatant meddlers, creators of disorder, fashioning before the spectator's eyes a negative anthropology, an anthropology of laughter. ${ }^{76}$

With the image of satyr play in mind, readers of the elaborate reconstruction of the polis by Socrates and his associates might easily see it fitting this description of satyr drama, and interpret it as a parody, and not as a serious proposal for actual cities. ${ }^{77}$ Such an interpretation would be readily reinforced by Socrates's frequent mentions of laughter from hypothetical onlookers.

\section{Metatheatricality in Plato's Republic.}

Over the last two decades, scholars have detected a significant flowering of metatheatricality in Greek tragedy and comedy through the latter part of the fifth century. Both genres 'came to exhibit a heightened awareness of their creative powers and their own theatricality as influential forces in the Athenian 
polis'. ${ }^{78}$ As theatrical events involved into celebrations of the city itself, 'the polis became a theater of literary and political fictions played by the demos to itself. This process ... was animated by the impulse to call established values, institutions, and practices into question'. ${ }^{79}$ But as Socrates's disciples later lamented, the demos was not receptive to the wide-open philosophical questioning of philosophers. So it is that Plato grasped the possibilities of using the new dramatic form of written dialogues to promote philosophical inquiry in a way that could question all beliefs without openly promoting views that would offend popular culture and bring personal disaster. Writing to the next generation as a lapsed poet and as an author of philosophical dialogues, it seems clear that Plato had fully embraced the complexities of metatheatricality in his own approach, and that adequate interpretation of his dialogues today requires careful attention to that dimension of his writings.

While the concept of metatheatricality is still evolving and is still employed with some variation of meaning, most scholars now use it to indicate that dramatists have built important meanings into their scripts that transcend or exceed the meanings of the words in the text. This is accomplished through a variety of techniques that exploit the fictionality of the written artifact by calling attention to the distinction between fiction and reality. ${ }^{80}$ The self-awareness of such texts signals alert readers to watch for invitations from the author to enter into dialogue with him directly. Several elements in Plato's Republic and in other dialogues match up with techniques developed by an earlier generation of dramatists. Borrowing forms or stereotypical components from other dramatic 
genres is one of the best documented of these techniques. Others include the idea of inserting plays or stories inside a play, or even having a principal character organize and direct such internal productions. Sometimes the author explicitly compares genres or promotes the virtues of his own chosen genre in these comparisons. Another well-attested technique is the borrowing and reformulating of scenes in one dramatic genre for use in another. ${ }^{81}$ In all of these, authors can find ways of reversing meaning. Once the audience sees what is going on, the story on stage can be seen as a product of the characters in the story, and its teachings can be seen to arise from their limited or flawed understandings and characters. In this way, the author addresses his audience or readers over the heads of the characters in the play to make his own points about politics, culture, religion, or philosophy—his own critique of the polis. Plato's repeated use of satyr-play stereotypes accomplishes that same purpose in Republic. ${ }^{82}$ Recognizing this invites an investigation of other guides to metatheatricality in this text as well as in other dialogues of Plato.

Some observers of this phenomenon have noted an inherent tendency toward democratization when public entertainment evolves into a mode of raising public issues and steering critique of public policies and morals. This may give us some insight about Plato's choice to give up writing drama for the general public in favor of the newly emerging dialogue genre that could be directed to a far narrower and more intellectualized audience. Further, the written dialogue does not allow the interposition of actors and directors between the writer and his audience — giving Plato complete control over the final product. ${ }^{83}$ Yet it does 
permit him to employ the techniques of metatheatricality developed by the dramatists of the preceding generation to establish multiple levels of discoursewith the unstated indirect communication between the writer and his elite audience serving as the vehicle for communication of the philosopher's most serious thoughts to those readers who may be capable of following his reasoning. In the process, the author intentionally creates multiple layers of meaning, which can, in effect, serve to sort his readers according to the expectations, prejudices, and intellectual skills they bring to the text. In this way, the author of dialogues could invert the democratizing effect that metatheatricality in tragedy and comedy had on Athenian audiences and promote serious, but safe philosophical investigation, and hopefully avoid Socrates's fate.

\section{Conclusion}

This paper identifies a wide array of conventional elements from satyr plays that are incorporated unobtrusively into Plato's Republic. Furthermore, it shows that this phenomenon is not likely incidental as the entire constellation of satyr-play themes that have been identified in the scholarly literature are well represented in this single dialogue, including even specific examples borrowed from well-known satyr plays. The Republic is not, however, a satyr play and is very far from being like one in many other respects. So why does Plato appear to systematically build the narrative themes of satyr play into his greatest dialogue?

I have suggested earlier Plato's need to signal to the readers of his new kind of dramatic writing the kinds of expectations they should have about the genre, or at least this particular dialogue. Borrowing overtly from the tragicomedy 
known to Athenians could minimally indicate to that audience that they should approach this new form of drama with some of the same expectations they brought to satyr play. In so doing, readers would recognize immediately that the tone suggested by the author was not the same as the seriousness and intelligence demonstrated by the characters with whom Socrates discusses justice. Plato has given his readers a clear signal that the understandings being taken so seriously by Glaucon and Adimantus may be rather humorous when seen from the perspective of the writer. Further, as we prepare ourselves to see irony in Socrates's strange political proposal, we should remember that satyric drama 'plays in a different key, with the displacement, distortion, and reversal of what constitutes the world and culture of men' ${ }^{84}$ That recognition invites us to read the Republic ironically as we try to discover the assumptions and beliefs that would then make sense of the text's serious teachings from this more distant perspective.

Satyr play introduces a comic mode without involving the characters in burlesque and without dissolving the distance between audience and characters, as occurs regularly in comedy. ${ }^{85}$ As in tragedy and satyr play, Plato's dialogue maintains that distance, presenting the Republic as a narration by Socrates to unknown auditors. No audience is present to get mixed up with the characters, to undermine the fiction of the stage. And so, the characters can carry on in high seriousness a conversation that is seen by a distant audience of readers to be full of irony and even comedy — even while he treats a very serious question. 


\section{Notes}

1. Noel B. Reynolds is professor of political science emeritus at Brigham Young University, Provo, Utah. Email noel_reynolds@byu.edu.

2. When Dorothy Tarrant looked at this issue in 1955, she acknowledged that ‘editors and translators have long recognized the dramatic element in Plato’s work', but she went on to observe that there was little scholarly work that studied this element closely. And in her own survey of dramatic elements in the dialogues, she did not claim to see any substantial connection between those elements and the themes or arguments involved. See 'Plato as Dramatist', The Journal of Hellenic Studies 75 (1955), pp. 82-89, at p. 82. Charles H. Kahn, Plato and the Socratic Dialogue: The Philosophical Use of a Literary Form (Cambridge 1996), is one of the most significant attempts by a prominent classicist to promote the kind of connections that political theorists and others have been exploring over the last half century.

3. As A. E. Taylor warned many years ago, to 'avoid serious errors, it is necessary always to remember that the personages of one of Plato's philosophical dialogues are one and all characters in a play.... In determining which of the views of his hero are put forward as his own, we ... have to observe much the same conditions and practise much the same precautions as are required for similar interpretation of a great dramatist or novelist', Plato (New York, 1911), pp. 31-33. It should be noted that Taylor leveraged this insight principally to 
distance the fictionalized characters in Plato's dialogues from their historical counterparts and not to question straightforward readings of the dialogues. Jacob Howland, 'Plato's Apology as Tragedy', The Review of Politics, 70/4 (Fall 2008), pp. 519-46, has argued impressively that Plato has embedded key features of tragedy into his Apology that ultimately serve to reveal 'the city of Athens (represented by the jury) [as] the true tragic protagonist of the Apology', p. 520. See also, for example, William Chase Greene, 'The Spirit of Comedy in Plato', Harvard Studies in Classical Philology 31 (1920), pp. 63-123; Helmet Kuhn, 'The True Tragedy, On the Relationship Between Greek Tragedy and Plato', Harvard Studies in Classical Philology 52 (1941), pp. 1-40 and p. 53; (1942), pp. 37-88; Kent F. Moors, 'Plato's Use of Dialogue', The Classical World 72 (1978), pp. 77-93; Jerrald Ranta, 'The Drama of Plato's Ion', The Journal of Aesthetics and Art Criticism 26 (1967), pp. 219-29; and Arlene Saxonhouse, 'Comedy in Callipolis: Animal Imagery in the Republic', The American Political Science Review 72 (1978), pp. 888-901. A valuable outline of the history of Platonic interpretation is E. N. Tigerstedt, Interpreting Plato (Stockholm, 1976). Julia Annas poses a significant challenge to interpretive assumptions that have dominated Plato studies for over a century in Platonic Ethics, Old and New (Ithaca, 1999).

4. J. Peter Euben, The Tragedy of Political Theory: The Road Not Taken (Princeton, 1990), p. 50.

5. Euben, Tragedy of Political Theory, p. 3. The social context of Athenian 
drama in the fifth century is the subject of John J. Winkler and Froma L. Zeitlin, eds. Nothing To Do with Dionysos? Athenian Drama in its Social Context (Princeton, 1990).

6. Kahn, Plato and the Socratic Dialogue, assembles the evidence that Plato picked up on the idea of dialogues from earlier students of Socrates and perfected it in works that develop his own philosophical agenda.

7. This assumption is generally shared by students of Plato's dialogues.

8. H. H. Bacon, 'Socrates Crowned', Virginia Quarterly Review 35 (1959), pp. $415-30$.

9. See David Sider, 'Plato's Symposium as Dionysian Festival', Quaderni Urbinati di Cultura Classica 33 (1980), pp. 41-56. Sider and Bacon take their lead from Gerhard Krüger, Einsicht und Leidenschaft (Frankfurt, 1939), pp. 8691.

10. Bruno Snell has collected several ancient references to Plato in this connection in his Tragicorum Graecorum Fragmenta (Göttingen, Germany, 1971), 1:46, pp. 185-86.

11. Alice Swift Riginos, Platonica: The Anecdotes Concerning the Life and Writings of Plato (Leiden, 1976), p. 44. After a thorough review of all ancient anecdotes relating to Plato's early activities as a wrestler, painter, soldier, and poet, Riginos goes on to the skeptical conclusion that all of these traditions may be artifacts of ancient attempts to manufacture biographies for Plato by mining his dialogues, and particularly by reading autobiographical facts into his discussions 
of the education of the guardians in Republic. See her discussion on pages 41-52. More recent literature — cited selectively in note 3 above, that illustrates Plato's awareness, concern, and sophistication regarding Greek poetry and drama-may provide occasion to reconsider that skepticism.

12. This point is made by many interpreters and is stated clearly by Clay Diskin in his Platonic Questions: Dialogues with the Silent Philosopher (University Park, 2000), p. 102. See also Noel B. Reynolds, Interpreting Plato's Euthyphro and Meno (Provo, 1988), pp. 20-24, for a discussion of Socrates as a Platonic character.

13. All references and quotations from Plato's Symposium can be found in the Loeb Classical Library volume trans. W. R. M. Lamb (Cambridge, Mass., 1925).

14. All references to the Republic are taken from Paul Shorey's translation, Loeb Classical Library (Cambridge, Mass., 1982).

15. Republic I, p. 233, note d.

16. See a defense of this view in Richard Patterson, 'The Platonic Art of Comedy and Tragedy', Philosophy and Literature 6/1-2 (1982), pp. 76-93. Compare to Sider, Plato's Symposium, p. 43. C. J. Rowe also suggests that Plato may be nominating himself as the one who has the necessary knowledge to be able to write both, C. J. Rowe, Plato (Brighton 1984), p. 151. It may be worth recalling in this context the account of Diogenes reported above, which describes Plato as a writer of tragedies and a transcriber of comedies for Epicharmus.

17. See the classic discussion in Wayne C. Booth, A Rhetoric of Irony 
(Chicago, 1974), pp. 49-86.

18. See Reynolds, Interpreting Plato's Euthyphro, pp. 14-20, for a discussion of Plato's use of some of these devices.

19. Winkler and Zeitlin, Nothing To Do with Dionysos, have questioned the standard distinction of satyr play as a separate genre. While recognizing that 'in the hierarchy of modern generic eminence, satyr-play obviously ranks a distant third after tragedy and comedy', they go on to remind us that 'in the scheme of the Attic festival the satyr-play was not a separate "genre". Rather, it was 'an element of the tragic competition, another performance by the same ensemble'. For that reason, they choose to 'place it with tragedy, not after comedy, in [their] scheme of things', p.7.

20. Important book-length studies of satyr play include Peter Guggisberg, Das Satyrspiel, PhD diss. (Zurich, 1947); N. Chourmouziades, Satyrika (Athens, 1974), and De Graecorum fabulis satyricis (Wroclaw, 1979); Dana F. Sutton, The Greek Satyr Play (Meisenheim am Glam, 1980); Richard Seaford, Euripides's Cyclops (Oxford, 1984); and George W. M. Harrison, ed., Satyr Drama: Tragedy at Play (Swansea, 2005).

21. Sutton, Greek Satyr Play. See also his earlier article, 'Satyr Plays and the Odyssey', Arethusa 7/2 (Winter 1974), pp. 161-85.

22. See also Richard Seaford, 'On the Origins of Satyric Drama', Maia 28 (1976), pp. 208-21.

23. Sutton's pioneering work is regarded as 'adventurous' by some classicists 
and specialists in ancient Greek drama, given the extreme fragmentary nature of the corpus of satyr play material. But the thematic proposals in his work have not been refuted, and they have been at least partially vindicated by subsequent studies, including this one, because of their fertility in advancing understanding. See the concerns articulated in John Gilbert, 'Recent Work on Satyr Play', Classical Journal 98/1 (2002), pp. 1-2, note 1.

24. N. E. Collinge, 'Some Reflections on Satyr-Plays', Proceedings of the Cambridge Philological Society 5 (1958/59), p. 28.

25. Collected in Snell, Tragicorum Graecorum, 1:186. Apparently describing the same event, Proclus credits Socrates's attack on the value of drama for turning Plato away from tragedy and toward Socratic dialogues, ibid. 1:186.

26. Whereas tragic style invariably is characterized by high poetry achieved by use of elevated vocabulary ... and by bold use of metaphor and other species of figurative imagery,' the style of satyr plays is usually more pedestrian and poetically unambitious. Sutton, Greek Satyr Play, p. 143.

27. Sutton, Greek Satyr Play, p. 158.

28. Seaford, 'Origins of Satyric Drama', pp. 26-33.

29. Sutton, Greek Satyr Play, p. 61. See also Dana F. Sutton, 'Father Silenus: Actor or Coryphaeus?' Classical Quarterly New Series 24/1 (May 1974), pp. 1923.

30. Ibid., pp. 178-79.

31. See Francis Redding Walton, 'A Problem in the Ichneutae of Sophocles', 
Harvard Studies in Classical Philology 46 (1935), pp. 167-89. The hunting imagery surfaces again at $432 \mathrm{~b}-\mathrm{d}$.

32. In his 'Introduction' to the Jowett translation of Plato's works, W. C. Green lists the characteristics which lead him to speak of the historical Socrates as a 'satyr-like creature'. See The Dialogues of Plato (New York, 1927), p. xvii. Benjamin Jowett himself once wrote in a preface to his translation of Cratylus that in some dialogues Plato intended to depict Socrates as Silenus. See the excerpts assembled by Lewis Campbell, Select Passages from the Introductions to Plato by Benjamin Jowett (London, 1902), p. 8.

33. M. D. Usher identifies this allusion to Silenus as a key to the understanding of the Symposium as a satyric composition. He further identifies the systematic references to Euripides's Cyclops to further emphasize the focus on satyric qualities in Socrates. See his 'Satyr Play in Plato's Symposium', The American Journal of Philology, 123/2 (Summer, 2002), pp. 205-28, esp. pp. 21923). Related commentary on this passage can be found in Leon Guilhamet, 'Socrates and Post-Socratic Satire', Journal of the History of Ideas 46 (1985), pp. 8-9.

34. Scholars have noticed a strong physical similarity between portraits of Socrates and masks of Sileni. See Carl Weickert, 'Maske eines Silens in Sammlung Loeb', Festschrift für James Loeb (Munich, 1930), pp. 107-8; and K. Kerenyi, 'Uomo e maschera', 12 Dioniso (1949), pp. 17-32.

35. H. J. Rose, A Handbook of Greek Mythology (London, 1958), pp. 111-12, 
145.

36. Sutton, Greek Satyr Play, p. 153; Seaford, 'Origins of Satyric Drama', p. 138.

37. Karl G. Galinsky, The Herakles Theme (Oxford, 1972), pp. 48, 78.

38. Galinsky, The Herakles Theme, p. 81.

39. Frank Brommer, Vaserlisten zur griechischen Heldersage (Marburg, 1973), pp.190-93.

40. Reynolds, Interpreting Plato's Euthyphro, p. 13.

41. Nicole Loraux, 'Socrate, Platon, Herakles: Sur un Paradigme Héroique du Philosophe', in J. Brunschwig, C. Imbert, and A. Roger, eds. Histoire et Structure: A la Mémoire de Victor Goldschmidt (Paris, 1985), pp. 93-105.

42. Galinsky, The Herakles Theme, p. 101.

43. Ibid., pp. 105-7.

44. M. S. Silk reminds us in 'Heracles and Greek Tragedy', Greece and Rome, 32/1 (1985), pp. 122, that the two Heraklean tragedies derive their emotional power from the fact that Herakles was neither god nor man, but somewhere in between — a mysterious liminal figure — for good and for ill.

45. Galinsky, The Herakles Theme, p. 45.

46. Ibid., p. 41.

47. Dana F. Sutton, 'The Satyr Play', The Cambridge History of Classical Literature (Cambridge, 1989), I, pt. 2, p. 94.

48. Sutton, Greek Satyr Play, p. 146. 
49. Ibid., p. 121.

50. Cf. Dana Sutton, 'Critias and Atheism', Classical Quarterly 31 (1981), pp. 33-38.

51. Patrick O'Sullivan, 'Of sophists, tyrants, and Polyphemos: the nature of the beast in Euripides' Cyclops', in Harrison, ed., Satyr Drama: Tragedy at Play.

52. Sutton, Greek Satyr Play, p. 146.

53. Ibid., p. 147.

54. Ibid., p. 148.

55. Ibid., p. 148.

56. Sutton, Greek Satyr Play, p. 174-75. For the more detailed argument, see Sutton, 'Satyr Play and the Odyssey.'

57. Ibid., p. 149.

58. Ibid., p. 122.

59. Sandra Peterson has recently published her analysis of the Platonic dialogues, in which she demonstrates how the arguments articulated by Socrates can be interpreted effectively as revelations of the beliefs of his interlocutors, rather than as indications of Plato's own philosophical beliefs. See Socrates and Philosophy in the Dialogues of Plato (Cambridge, 2011). Peterson achieves this insight without invoking literary analyses or irony, but by strictly following the actual words of Socrates in the dialogues.

60. Sutton, Greek Satyr Play, p. 150.

61. Ibid, p. 150. 
62. Ibid, p. 151.

63. Elizabeth Belfiore, 'Elenchus, Epode and Magic: Socrates as Silenus', Phoenix 34 (1980), pp. 128-37.

64. Sutton, Greek Satyr Play, p. 151.

65. Gregory W. Dobrov, 'Comedy and the Satyr-Chorus', The Classical World, 100/3 (2007), pp. 251-65, provides a helpful expansion of the analysis of the anodos scene in satyr play in his explanation of why Aristophanes's comedy Peace can use the same scene without violating its usual confinement to the satyrplay genre.

66. Sutton, Greek Satyr Play, p. 153.

67. Ibid, p. 44, note 137 .

68. See David Sider, 'The Structure of Plato Republic VI', Rivista di Studi Classici 24/3 (1976), p. 337, note 9 for a useful summary of scholarly discussions of this point.

69. See Werner Jobst, Die Höhle im Griechischen Theater des 5. und 4. Jahrhunderts v. Chr.: Eine Untersuchung zur Inszenierung Klassischer Dramen (Wien, 1970), p. 141.

70. Sutton, Greek Satyr Play, p. 154.

71. Ibid, p. 156.

72. Ibid, pp. $36,69,73-74$.

73. Ibid, p. 42.

74. See Sutton, Greek Satyr Play, pp. 158, 160, 162. 
75. Arlene Saxonhouse, 'Comedy in Callipolis', pp. 888-901.

76. François Lissarrague, 'What Satyrs Are Good to Represent', in Nothing To Do with Dionysos, ed. Winkler and Zeitlin, pp. 35-36.

77. Sandra Peterson comes to a similar conclusion using her nonliterary methodology, Socrates and Philosophy, pp. 147-48.

78. Gregory W. Dobrov, Figures of Play: Greek Drama and Metafictional Poetics (Oxford, 2001), p. 4. Dobrov goes on to quote Jean-Paul Vernant, in J. P. Vernant and P. Vidal-Naquet, Myth and Tragedy in Ancient Greece, tr. J. Lloyd Sussex (New York, 1990), p. 33: 'The city established . . . a spectacle open to all citizens, directed, acted, and judged by the qualified representatives of the various tribes'. In this way tragedy 'turned itself into a theater; its subject, in a sense, was itself and it acted itself out before the public'.

79. Dobrov, Figures of Play, p. 5.

80. Ibid, p. 9 .

81. Sutton recognized early on the possibility that a primary purpose of the satyr plays included in the tragic tetralogies was to relieve the psychological tension by putting the horror of tragedy into a comic perspective and to transpose the heroic morality of the tragedy into the ordinary morality of normal human life. See his doctoral thesis, The Date of Euripides' Cyclops (University Microfilms, 1974), pp. 193-96.

82. Dobrov challenges the dominant view long promoted by Lissarrague that satyr play does not exhibit the kind of reflexivity scholars are now finding in 
tragedy and comedy. Dobrov, Figures of Play, p. 7.

83. Plato's choice to write for 'silent readers' is discussed in Jesper Svenbro,

'The "Interior" Voice: On the Invention of Silent Reading', in Winkler and

Zeitlin, Nothing To Do with Dionysos, pp. 366-84 at 379.

84. Lissarrague, 'What Satyrs Are Good to Represent', p. 236.

85. Ibid. 